\title{
PENGARUH CEKAMAN AIR DAN PEMBERIAN PUPUK DAUN TERHADAP PERTUMBUHAN TANAMAN SAWI (Brassica juncea L.)
}

\author{
Netty Nurjanaty ${ }^{1}$, Riza Linda ${ }^{1}$, Mukarlina ${ }^{1}$ \\ ${ }^{1}$ Program Studi Biologi, Fakultas MIPA, Universitas Tanjungpura, Jl. Prof. Dr. H. Hadari Nawawi, Pontianak \\ Email korespondensi: nettynurjanaty@gmail.com
}

\begin{abstract}
The availability of water for plants will affect the process of plant growth. Water stress in plants can be overcome by applying fertilizer. Fertilizing through leaves has the advantage of absorbing nutrients needed to speed up the growth process. The purpose of this research was to use a completely randomized design (CRD) with two factors, namely the A factor of water supply consisting of $100 \%$ field capacity (KL) (A1), 75\% KL (A2), $125 \% \mathrm{KL}(\mathrm{A} 3)$, B concentration factor leaf fertilizer consists of $0 \mathrm{~g} / \mathrm{L}$ (B1), 1,5 g/L (B2), $2 \mathrm{~g} / \mathrm{L}$ (B3), $2,5 \mathrm{~g} / \mathrm{L}$ (B4), and $3 \mathrm{~g} / \mathrm{L}$ (B5) so that there is 15 combinations of treatments with 5 replications. Based on the results of research on the stress conditions of $75 \%, 100 \%$, and $125 \% \mathrm{KL}$ the best leaf fertilizer for growth of mustard green plants which includes leaf area, amount of chlorophyll, number of leaves, wet weight, dry weight, and root-shoot ratio is as much as $3 \mathrm{~g} / \mathrm{L}$.
\end{abstract}

Keyword : Brassica juncea L., field capacity, leaf fertilizer, growth

\section{PENDAHULUAN}

Tanaman sawi hijau (Brassica juncea L.) merupakan salah satu jenis tanaman sayuran yang menjadi komoditas utama di Kalimantan Barat. Pertumbuhan tanaman sawi membutuhkan tempat yang lembab, sedangkan pada musim panas perlu dilakukan penyiraman secara teratur (Usman, 2010). Kelembaban tanah sangat berpengaruh terhadap pertumbuhan tanaman. Ketidaksesuaian kelembaban tanah disebabkan oleh suplai air tidak diberikan dalam jumlah yang tepat (Adams et al., 2012). Kondisi lingkungan tertentu tanaman sawi dapat mengalami defisit air yang mengakibatkan cekaman air pada tanaman, sehingga defisit air akan menyebabkan penurunan gradien potensial air antara tanah-akar-daun-atmosfer, sehingga laju transpor air dan hara menurun yang dapat mempengaruhi hasil bobot segar tanaman sawi (Taiz \& Zeiger, 2002).

Ketersediaan air bagi tanaman mempengaruhi pertumbuhan tanaman. Cekaman (kelebihan maupun kekurangan) air dapat berakibat buruk karena akan mengganggu proses-proses metabolisme dalam tubuh tanaman. Menurut penelitian Moctava et al., (2013), pada perlakuan 70\% kapasitas lapang menghasilkan jumlah daun dan bobot segar sawi lebih tinggi dibandingkan dengan perlakuan 30\% kapasitas lapang.

Tanaman yang mengalami cekaman memerlukan unsur lain dalam proses mendukung pertumbuhan, salah satunya dengan cara pemupukan. Pemu pukan dapat dilakukan melalui tanah dan atau melalui daun dengan cara penyemprotan secara langsung pada daun. Pemupukan melalui daun memiliki keuntungan dalam penyerapan hara yang diperlukan untuk mempercepat proses pertumbuhan dan penyerapan unsur hara yang akan dimanfaatkan oleh daun (Hardjowigeno, 2003; Lingga dan Marsono, 2007).

Penelitian yang dilakukan Sari et al., (2011), pengaruh cekaman air dan pemberian pupuk daun pada tanaman anggrek terjadi interaksi pada parameter berat basah tanaman 56 hari setelah tanam dan berpengaruh pada luas daun umur 28 hari setelah tanam pada konsentrasi pupuk daun sebesar $1 \mathrm{~g} / \mathrm{L}$ dan pemberian air $10 \mathrm{cc} /$ pot.

Hasil penelitian Shobirin (2015), menunjukkan bahwa berat kering dan bobot basah tanaman kangkung (Ipomea reptans) yang diberi pupuk daun $2,5 \mathrm{~g} / \mathrm{L}$ meningkat sebesar $5,5 \%$ dan $21,1 \%$ dibandingkan pemberian pupuk daun $2,0 \mathrm{~g} / \mathrm{L}$ dan $1,5 \mathrm{~g} / \mathrm{L}$. 
Penelitian mengenai pengaruh cekaman air dan pemberian pupuk daun pada tanaman sawi hijau belum dilakukan. Sehubungan dengan itu, maka perlu dilakukan penelitian mengenai pengaruh pemberian pupuk daun pada tanaman sawi yang mengalami cekaman air.

\section{BAHAN DAN METODE}

\section{Waktu dan Tempat Penelitian}

Penelitian dilakukan pada bulan Juli sampai Agustus 2018. Penelitian dilaksanakan di Rumah Kasa dan Laboratorium Biologi Jurusan Biologi Fakultas Matematika dan Ilmu Pengetahuan Alam Universitas Tanjungpura. Analisis tanah dilakukan di Laboratorium Kimia dan Kesuburan Tanah Fakultas Pertanian Universitas Tanjungpura.

\section{Bahan}

Bahan-bahan yang digunakan pada penelitian ini adalah air, bibit tanaman sawi (Brassica juncea L.) varietas Shinta, pupuk daun merk 'Gandasil D', dan tanah gambut.

\section{Metode Penelitian}

Penelitian ini menggunakan Rancangan Acak Lengkap (RAL) dengan dua faktor yaitu faktor A cekaman air terdiri atas 100\% KL (A1), 75\% KL (A2), 125\% KL (A3), faktor B konsentrasi pupuk daun terdiri atas $0 \mathrm{~g} / \mathrm{L}(\mathrm{B} 1), 1,5 \mathrm{~g} / \mathrm{L}(\mathrm{B} 2), 2 \mathrm{~g} / \mathrm{L}$ (B3), 2,5 g/L (B4), dan $3 \mathrm{~g} / \mathrm{L}$ (B5) sehingga terdapat 15 kombinasi perlakuan dengan masingmasing 5 kali ulangan sehingga terdapat 75 unit percobaan.

\section{Prosedur Kerja}

\section{Penentuan Kapasitas Lapang}

Penentuan Kapasitas Lapang (KL) dilakukan dengan mengisi 5 buah pot dengan media tanam berupa tanah gambut sebanyak 500 gram. Semua pot disiram sampai keadaan jenuh dan dibiarkan selama 3 × 24 jam sampai air tidak menetes lagi, selanjutnya tanah ditimbang sebagai berat basah (Tb). Tanah dimasukkan ke dalam oven pada suhu $100^{\circ} \mathrm{C}$ selama 5 hari kemudian dikeluarkan dari oven dan ditimbang sebagai berat kering (Tk).

Menurut Herdiawan (2013), KL tanah dihitung denganmenggunakan rumus:

$\mathrm{KL}=\frac{\mathrm{Tb}(\mathrm{g})-\mathrm{Tk}(\mathrm{g})}{\mathrm{Tk}(\mathrm{g})} \times 100 \%$

Keterangan :

KL : Kapasitas Lapang

$\mathrm{Tb}:$ Berat Basah

Tk : Berat Kering

\section{Persiapan Media Tanam}

Media tanam berupa tanah dikeringanginkan terlebih dahulu selama 7 hari kemudian diayak. Sebanyak $2 \mathrm{~kg}$ tanah tanah dimasukkan ke dalam polibag.

\section{Penyemaian dan Penanaman}

Biji sawi disemai di polibag yang berisi tanah gambut, kemudian tanaman sawi yang telah mencapai 14 hari setelah tanam atau tanaman telah memiliki 3 helai daun dipindahkan pada media tanam. Kemudian bibit yang telah disemai ditanam pada masing-masing polibag dengan berisi 1 tanaman.

\section{Perlakuan Cekaman Air dan Pemberian Pupuk Daun}

Perlakuan diberikan ketika tanaman berusia 7 hari setelah tanam dan dipindahkan pada media tanam. Perlakuan pemberian volume penyiraman terdiri atas $75 \% \mathrm{KL}, 100 \% \mathrm{KL}$, dan $125 \%$ KL dilakukan setiap hari pada kisaran waktu pukul $07.00-09.00$ WIB. Penyiraman dilakukan dengan meletakkan polibag ke dalam wadah, air yang keluar dari polibag akan tertampung pada wadah untuk kemudian disiramkan kembali pada tanaman. Pemberian konsentrasi pupuk 'gandasil D' yang terdiri atas $0 \mathrm{~g} / \mathrm{L}, 1,5 \mathrm{~g} / \mathrm{L}, 2 \mathrm{~g} / \mathrm{L}, 2,5 \mathrm{~g} / \mathrm{L}$ dan $3 \mathrm{~g} / \mathrm{L}$ dilakukan setiap 3 hari sekali dengan cara disemprotkan pada bagian bawah daun pada kisaran pukul 07.00-09.00 WIB (Aditama, 2011). Masing-masing perlakuan dilakukan sampai tanaman sawi berumur 40 hari.

\section{Penyiangan}

Penyiangan dilakukan secara mekanik dengan mencabut gulma yang tumbuh pada media tanaman.

\section{Parameter Pengamatan}

Parameter yang diamati pada penelitian ini diantaranya luas daun $\left(\mathrm{cm}^{2}\right)$, jumlah klorofil (spad unit), jumlah daun (helai), berat basah tajuk (g), berat kering tajuk $(\mathrm{g})$, berat basah akar $(\mathrm{g})$, berat kering akar (g) dan rasio akar-tajuk (g).

\section{Analisis Data}

Data-data yang dihasilkan dianalisis menggunakan Analisis of Varians (ANOVA) dua jalur. Perbedaan antar perlakuan dianalisis lanjut menggunakan Duncan's Multi Range Test (DMRT) dengan taraf kepercayaan 95\% $(\mathrm{P}<0,05)$ (Hanafiah, 2004). 


\section{HASIL DAN PEMBAHASAN}

\section{Hasil}

Luas Daun, Jumlah Klorofil, dan Jumlah Daun

Berdasarkan hasil analisis ANOVA menunjukkan bahwa perlakuan kombinasi cekaman air dan pemberian pupuk daun berpengaruh nyata terhadap luas daun tanaman sawi $\left(F_{14,60}=6,980, \rho=0,00\right)$ dan jumlah klorofil $\left(\mathrm{F}_{14,60}=8,717, \rho=0,000\right)$, sedangkan pada jumlah daun tidak terdapat interaksi antara cekaman air dan pemberian pupuk daun $\left(F_{14,60}=1,468, \rho=0,188\right)$.

Tabel 1 Rerata luas daun, jumlah klorofil, dan jumlah daun tanaman sawi (B. juncea) pada kombinasi cekaman air dan pupuk daun 40 hari setelah tanam

\begin{tabular}{|c|c|c|c|}
\hline Kombinasi Perlakuan & $\begin{array}{l}\text { Luas daun } \\
\qquad\left(\mathrm{cm}^{2}\right)\end{array}$ & $\begin{array}{l}\text { Jumlah } \\
\text { klorofil } \\
\text { (spad } \\
\text { unit) }\end{array}$ & $\begin{array}{l}\text { Jumlah } \\
\text { daun } \\
\text { (helai) }\end{array}$ \\
\hline A1B1 (100\% KL+ $0 \mathrm{~g} / \mathrm{L})$ & $38,20^{\mathrm{ab}}$ & $35,44^{\mathrm{ab}}$ & $6,60^{\mathrm{a}}$ \\
\hline A1B2 (100\% KL+1,5 g/L) & $39,60^{\mathrm{ab}}$ & $37,90^{\mathrm{abcd}}$ & $6,60^{\mathrm{a}}$ \\
\hline A1B3 $(100 \% \mathrm{KL}+2 \mathrm{~g} / \mathrm{L})$ & $57,40^{\text {de }}$ & $44,84^{\mathrm{abcd}}$ & $6,60^{\mathrm{a}}$ \\
\hline A1B4 $(100 \% \mathrm{KL}+2,5 \mathrm{~g} / \mathrm{L})$ & $61,80^{\mathrm{ef}}$ & $48,94^{\text {cde }}$ & $8,00^{\mathrm{a}}$ \\
\hline A1B5 $(100 \% \mathrm{KL}+3 \mathrm{~g} / \mathrm{L})$ & $61,60^{\mathrm{ef}}$ & $60,00^{\mathrm{e}}$ & $7,80^{\mathrm{a}}$ \\
\hline A2B1 (75\% KL + $0 \mathrm{~g} / \mathrm{L})$ & $31,00^{\mathrm{a}}$ & $33,98^{\mathrm{a}}$ & $5,40^{\mathrm{a}}$ \\
\hline A2B2 $(75 \% \mathrm{KL}+1,5 \mathrm{~g} / \mathrm{L})$ & $42,20^{\mathrm{bc}}$ & $40,64^{\text {abcd }}$ & $5,80^{\mathrm{a}}$ \\
\hline A2B3 $(75 \% \mathrm{KL}+2 \mathrm{~g} / \mathrm{L})$ & $37,40^{\mathrm{abc}}$ & $45,93^{\mathrm{abcd}}$ & $6,20^{\mathrm{a}}$ \\
\hline A2B4 $(75 \% \mathrm{KL}+2,5 \mathrm{~g} / \mathrm{L})$ & $43,00^{\mathrm{bc}}$ & $48,14^{\text {bcde }}$ & $6,60^{\mathrm{a}}$ \\
\hline A2B5 $(75 \% \mathrm{KL}+3 \mathrm{~g} / \mathrm{L})$ & $71,00^{\mathrm{f}}$ & $46,00^{\mathrm{abcd}}$ & $7,00^{\mathrm{a}}$ \\
\hline A3B1 $(125 \% \mathrm{KL}+0 \mathrm{~g} / \mathrm{L})$ & $43,60^{\mathrm{bc}}$ & $36,84^{\mathrm{abc}}$ & $5,20^{\mathrm{a}}$ \\
\hline A3B2 $(125 \% \mathrm{KL}+1,5 \mathrm{~g} / \mathrm{L})$ & $50,00^{\mathrm{cd}}$ & $41,48^{\mathrm{abcd}}$ & $5,60^{\mathrm{a}}$ \\
\hline A3B3 $(125 \% \mathrm{KL}+2 \mathrm{~g} / \mathrm{L})$ & $54,00^{\mathrm{de}}$ & $50,96^{\text {de }}$ & $6,20^{\mathrm{a}}$ \\
\hline A3B4 $(125 \% \mathrm{KL}+2,5 \mathrm{~g} / \mathrm{L})$ & $60,80^{\mathrm{e}}$ & $45,93^{\mathrm{abcd}}$ & $7,00^{\mathrm{a}}$ \\
\hline A3B5 $(125 \% \mathrm{KL}+3 \mathrm{~g} / \mathrm{L})$ & $54,00^{\text {de }}$ & $39,20^{\text {abcd }}$ & $6,40^{\mathrm{a}}$ \\
\hline $\begin{aligned} \text { Keterangan : } & \text { Angka yang } \\
& \text { menunjukkan } \\
& \text { menurut uji } \\
& 95 \% .\end{aligned}$ & $\begin{array}{l}\text { diikuti ol } \\
\text { hasil yan } \\
\text { Duncan pa }\end{array}$ & $\begin{array}{l}\text { huruf } y \\
\text { idak berb }\end{array}$ & $\begin{array}{l}\text { sama } \\
\text { nyata }\end{array}$ \\
\hline
\end{tabular}

Parameter luas daun pada perlakuan A1B1 berbeda nyata dengan A1B3, A1B4 dan A1B5, tetapi A1B3, A1B4 dan A1B5 tidak berbeda nyata. Perlakuan A2B1 berbeda nyata dengan A2B2, A2B4, dan A2B5, tetapi A2B2, A2B3, dan A2B4 tidak berbeda nyata. Perlakuan A3B1 berbeda nyata dengan $\mathrm{A} 3 \mathrm{~B} 3, \mathrm{~A} 3 \mathrm{~B} 4$, tetapi $\mathrm{A} 3 \mathrm{~B} 3, \mathrm{~A} 3 \mathrm{~B} 4$, dan A3B5 tidak berbeda. Luas daun tanaman terbesar yaitu $71,00 \mathrm{~cm}^{2}$. Pemberian pupuk daun 2,5 dan $3 \mathrm{~g} / \mathrm{L}$ tidak berbeda nyata terhadap luas daun dan sudah mampu memberikan hasil luas daun yang baik pada keadaan kapasitas lapang (100\%) maupun keadaan air berlebih (125\% KL), pada keadaan air $75 \% \mathrm{KL}$ dengan pemberian $3 \mathrm{~g} / \mathrm{L}$ pupuk daun menghasilkan luas daun terbesar yaitu $71,00 \mathrm{~cm}^{2}$.
Parameter jumlah klorofil perlakuan A1B1 tidak berbeda nyata dengan A2B1 dan A3B1. Perlakuan A1B5 berbeda nyata dengan A1B1, A1B2, dan A1B3, tetapi tidak berbeda nyata dengan A1B4. Perlakuan A2B4 berbeda nyata dengan A2B1 tetapi tidak berbeda nyata dengan perlakuan lainnya. A3B3 berbeda nyata dengan A3B1. Nilai klorofil tertinggi terdapat pada perlakuan A1B5 didengan 60,00 spad unit. Perlakuan kombinasi cekaman air dan pemberian pupuk daun terhadap parameter jumlah daun tidak terdapat adanya interaksi, jumlah daun terbanyak terdapat pada perlakuan kombinasi A1B4 yaitu sebanyak 8 helai.

\section{Berat Basah, Berat Kering dan Rasio Akar Tajuk}

Berdasarkan hasil analisis ANOVA menunjukkan bahwa terjadi interaksi kombinasi antara cekaman air dan pupuk daun terhadap berat basah tajuk $\left(F_{14,60}=2,527, \rho=0,019\right)$, berat kering tajuk $\left(F_{14,60}\right.$ $=3,325, \rho=0,003)$, berat basah akar $\left(\mathrm{F}_{14,60}=\right.$ $5,376, \rho=0,000)$, berat kering akar $\left(F_{14,60}=4,733\right.$, $\rho=0,000)$, dan rasio akar tajuk tanaman sawi $\left(\mathrm{F}_{14,60}=9,994, \rho=0,000\right)$.

Tabel 2 Rerata berat basah, berat kering dan rasio akartajuk tanaman sawi (B. juncea) pada kombinasi cekaman air dan pupuk daun 40 hari setelah tanam

\begin{tabular}{|c|c|c|c|}
\hline Kombinasi Perlakuan & $\begin{array}{c}\text { Berat } \\
\text { basah } \\
\text { total }(\mathrm{g})\end{array}$ & $\begin{array}{l}\text { Berat } \\
\text { kerin } \\
\mathrm{g} \text { total } \\
(\mathrm{g})\end{array}$ & $\begin{array}{l}\text { Rasio } \\
\text { akar- } \\
\text { tajuk } \\
(\mathrm{g})\end{array}$ \\
\hline A1B1 (10\%KL+0 g/L) & $18,80^{\mathrm{cd}}$ & $1,30^{\mathrm{bc}}$ & $0,40^{\mathrm{e}}$ \\
\hline A1B2 $(100 \% \mathrm{KL}+1,5 \mathrm{~g} / \mathrm{L})$ & $19,41^{\mathrm{cd}}$ & $1,44^{\mathrm{bc}}$ & $0,10^{\mathrm{c}}$ \\
\hline A1B3 $(100 \% \mathrm{KL}+2 \mathrm{~g} / \mathrm{L})$ & $20,67^{\mathrm{cd}}$ & $1,90^{\mathrm{cd}}$ & $0,25^{\mathrm{d}}$ \\
\hline A1B4 $(100 \% \mathrm{KL}+2,5 \mathrm{~g} / \mathrm{L})$ & $22,85^{\mathrm{d}}$ & $2,12^{\mathrm{cd}}$ & $0,05^{\mathrm{abc}}$ \\
\hline A1B5 $(100 \% \mathrm{KL}+3 \mathrm{~g} / \mathrm{L})$ & $23,33^{\mathrm{d}}$ & $2,61^{\mathrm{d}}$ & $0,09^{\mathrm{bc}}$ \\
\hline A2B1 $(75 \% \mathrm{KL}+0 \mathrm{~g} / \mathrm{L})$ & $7,12^{\mathrm{a}}$ & $0,41^{\mathrm{a}}$ & $0,06^{\mathrm{a}}$ \\
\hline A2B2 $(75 \% \mathrm{KL}+1,5 \mathrm{~g} / \mathrm{L})$ & $8,73^{\mathrm{a}}$ & $0,96^{\mathrm{ab}}$ & $0,12^{\mathrm{a}}$ \\
\hline $\mathrm{A} 2 \mathrm{~B} 3(75 \% \mathrm{KL}+2 \mathrm{~g} / \mathrm{L})$ & $8,76^{\mathrm{a}}$ & $0,73^{\mathrm{ab}}$ & $0,06^{\mathrm{a}}$ \\
\hline A2B4 $(75 \% \mathrm{KL}+2,5 \mathrm{~g} / \mathrm{L})$ & $9,69^{\mathrm{ab}}$ & $0,87^{\mathrm{ab}}$ & $0,26^{\mathrm{a}}$ \\
\hline $\mathrm{A} 2 \mathrm{~B} 5(75 \% \mathrm{KL}+3 \mathrm{~g} / \mathrm{L})$ & $20,52^{\mathrm{cd}}$ & $1,44^{\mathrm{bc}}$ & $0,66^{\text {bcde }}$ \\
\hline A3B1 $(125 \% \mathrm{KL}+0 \mathrm{~g} / \mathrm{L})$ & $12,40^{\mathrm{abc}}$ & $0,94^{\mathrm{ab}}$ & $0,03^{\mathrm{abc}}$ \\
\hline A3B2 $(125 \% \mathrm{KL}+1,5 \mathrm{~g} / \mathrm{L})$ & $14,25^{\mathrm{abc}}$ & $0,92^{\mathrm{ab}}$ & $0,08^{\mathrm{bc}}$ \\
\hline A3B3 $(125 \% \mathrm{KL}+2 \mathrm{~g} / \mathrm{L})$ & $14,30^{\mathrm{abc}}$ & $0,99^{\mathrm{ab}}$ & $0,02^{\mathrm{ab}}$ \\
\hline A3B4 $(125 \% \mathrm{KL}+2,5 \mathrm{~g} / \mathrm{L})$ & $17,76^{\text {bcd }}$ & $1,99^{\mathrm{cd}}$ & $0,03^{\mathrm{abc}}$ \\
\hline A3B5 $(125 \% \mathrm{KL}+3 \mathrm{~g} / \mathrm{L})$ & $25,29^{\mathrm{d}}$ & $2,65^{\mathrm{d}}$ & $0,01^{\mathrm{a}}$ \\
\hline $\begin{aligned} \text { Keterangan : } & \text { Angka yang } \\
& \text { menunjukkan } \\
& \text { menurut uji } \\
& 95 \% .\end{aligned}$ & kuti & & g sama \\
\hline
\end{tabular}

Berdasarkan hasil analisis ANOVA menunjukkan bahwa parameter berat basah total pada perlakuan $100 \%$ KL (A1) tidak berbeda nyata dengan semua pemberian pupuk daun, tetapi nilai berat basah total mengalami kenaikan sejalan dengan 
konsentrasi pemberian pupuk daun yang meningkat. Berat basah total pada cekaman $75 \%$ KL dengan semua konsentrasi pemberian pupuk daun memperlihatkan nilai rerata terendah dibandingkan yang lainnya $(100 \% \quad \mathrm{KL}$ dan $125 \% \mathrm{KL}$ ), perlakuan A2B5 berbeda nyata dengan A2B1, A2B2, A2B3, dan A2B5. Berat basah pada cekaman kelebihan $(125 \% \mathrm{KL})$ pada perlakuan A3B4 tidak berbeda nyata dengan A3B4, tetapi berbeda nyata dengan perlakuan A3B1, A3B2, A3B3. Berat basah tertinggi pada perlakuan cekaman $100 \% \mathrm{KL}, 75 \% \mathrm{KL}$ dan $125 \% \mathrm{KL}$ yaitu pada pemberiann pupuk daun $3 \mathrm{~g} / \mathrm{L}$ yaitu masingmasing 23,33 g, 20,52 g, dan 25,29 g (Tabel 2).

Berdasarkan hasil analisis ANOVA menunjukkan bahwa berat kering total tertinggi pada cekaman air $100 \% \mathrm{KL}, 75 \% \mathrm{KL}$, dan $125 \% \mathrm{KL}$ adalah saat pemberian pupuk daun sebanyak $3 \mathrm{~g} / \mathrm{L}$ yaitu sebesar 2,61 g, 1,44 g, dan 2,65 g. Bersdasarkan hasil analisis ANOVA menunjukkan bahwa perlakuan A1B1 dan A1B3 berbeda nyata dari perlakuan lainnya tetapi menghasilkan rasio akar tajuk yang besar yaitu 0,40 dan 0,25 . Perlakuan tanpa pupuk daun $(0 \mathrm{~g} / \mathrm{L})$ memperlihatkan rasio yang semakin menurun ketika dikombinasikan dengan air di bawah dan di atas kapasitas lapang (75\% KL dan 125\% KL) (Tabel 2).

\section{Pembahasan}

Pertumbuhan tanaman peka terhadap cekaman air yang berhubungan dengan menurunnya turgoditas yang dapat menghentikan pembelahan dan pembesaran sel sehingga ukuran organ-organ tanaman menjadi lebih kecil (Manan dan Mahfudz, 2015). Menurut Gardner et al (1991), luas daun dan perpanjangan batang suatu tanaman saat pertumbuhan vegetatif dapat berkurang saat mengalami kekurangan air. Pupuk daun gandasil mengandung unsur nitrogen yang paling besar dibandingkan unsur lainnya yaitu sebesar 20\%.Gandasil D berbentuk kristal yang dilarutkan dalam air sehingga dapat dengan mudah diserap dan ditranslokasikan keseluruh bagian tanaman, sehingga mampu mendukung proses pertumbuhan dan perkembangan tanaman (Lingga dan Marsono, 2007).

Pertambahan luas dan jumlah daun dipengaruhi oleh adanya unsur Nitrogen $(\mathrm{N})$. Unsur nitrogen pada tanaman berfungsi merangsang pertumbuhan secara keseluruhan (Hardjowigeno, 1992; Lingga dan Marsono, 2007). Pupuk daun "Gandasil D" mengandung unsur hara makro lainya yaitu unsur fosfor $(\mathrm{P})$, kalium $(\mathrm{K})$, dan magnesium $(\mathrm{Mg})$ yang dibutuhkan tanaman dalam proses pertumbuhan. Unsur $\mathrm{K}$ pada tanaman berperan dalam memperkuat tubuh tanaman dalam menghadapi kekeringan (Lingga dan Marsono, 2007).

Jumlah klorofil terbaik terdapat pada perlakuan $100 \% \mathrm{KL}$ dengan pemberian pupuk daun $2,5 \mathrm{~g} / \mathrm{L}$, cekaman air $125 \% \mathrm{KL}$ dengan pemberian pupuk daun $2 \mathrm{~g} / \mathrm{L}$ memperlihatkan nilai yang baik, sedangkan pada keadaan cekaman air $75 \% \mathrm{KL}$, pupuk yang efektif diberikan adalah 2,5 g/L (tabel 1). Faktor utama pembentuk klorofil adalah nitrogen $(\mathrm{N})$, tanaman yang kekurangan unsur $\mathrm{N}$ akan menunjukkan gejala klorosis pada daun. Kekurangan air juga mempengaruhi penurunan konsentrasi klorofil. Penurunan konsentrasi klorofil daun terutama disebabkan kekurangan nitrogen dan magnesium. Ketersediaan air berkaitan dengan kemampuan terlarutnya unsur hara yang dibutuhkan tanaman. Semakin banyak air yang tersedia untuk fotosintesis maka semakin tinggi unsur hara yang masuk ke dalam tanaman. Nitrogen juga berperan dalam penyusunan protein dan protoplasma secara keseluruhan.

Jumlah daun, luas daun dan klorofil berpengaruh pada berat basah suatu tanaman. Berat basah pada cekaman $75 \% \mathrm{KL}$ dengan semua konsentrasi pupuk daun memperlihatkan nilai paling rendah dibandingkan dengan kombinasi lainnya (tabel 1). Hal ini didukung dengan pernyataan Manuhuttu dkk, (2014) bahwa berat basah tanaman merupakan pertambahan jumlah organ-organ tanaman seperti daun, batang, dan akar yang dipengaruhi oleh kadar air dan kandungan unsur hara yang ada di dalam sel-sel jaringan tanaman.

Kadar air yang kurang (75\% KL) mengganggu proses pertumbuhan tanaman sawi sehingga nilai berat basah nilai paling rendah dibandingkan dengan perlakuan kombinasi lain (tabel 2). Perlakuan 100\% KL dan 125\% KL ditambah 3 g/L pupuk daun pada berat basah memperlihatkan hasil yang tinggi, hal tersebut dikarenakan adanya pemberian pupuk daun yang mengandung unsur nitrogen yang membantu dalam pembentukan fotosintat yang selanjutnya digunakan untuk membentuk sel-sel baru, pemanjangan sel dan penebalan jaringan. Harjadi (1991) menyatakan bahwa ketersediaan air dan unsur hara berperan penting sebagai bahan untuk fotosintesis sehingga tingkat kecukupan hara yang cukup berperan dalam mempengaruhi biomassa dari suatu tanaman. Menurut Sitompul dan Guritno (1995) 
berat basah tanaman dipengaruhi oleh kelembaban serta kadar air didalam jaringan. Menurut Sarief (1986) bahwa kandungan air didalam tanaman akan meningkat sejalan dengan peningkatan kandungan nitrogen sehingga dapat meningkatkan bobot berat basah suatu tanaman.

Berat kering pada perlakuan kombinasi 100\% KL dengan semua konsentrasi pupuk dauntidak berbeda nyata, tetapi berat kering tertinggi terdapat pada perlakuan A1B5 yaitu 2,61 g, sedangkan pada perlakuan $75 \%$ KL dengan semua konsentrasi pupuk daun memperlihatkan rerata paling rendah dibandingkan kombinasi lainnya (tabel 2). Berat kering pada perlakuan $75 \% \mathrm{KL}$ ditambah $3 \mathrm{~g} / \mathrm{L}$ pupuk daun sudah mampu memberikan nilai yang baik yaitu $1,44 \mathrm{~g}$. Perlakuan $125 \%$ KL dengan konsentasi pemberian pupuk daun $2,5 \mathrm{~g} / \mathrm{L}$ dan $3 \mathrm{~g} / \mathrm{L}$ tidak berbeda nyata, tetapi berbeda nyata dengan pemberian pupuk daun konsentrasi $0 \mathrm{~g} / \mathrm{L}, 1,5 \mathrm{~g} / \mathrm{L}$, dan $2 \mathrm{~g} / \mathrm{L}$. Berat kering tertinggi adalah pada kombinasi cekaman $125 \% \mathrm{KL}$ dan pemberian pupuk $3 \mathrm{~g} / \mathrm{L}$ yaitu sebesar 2,65 g.

Berat kering merupakan akumulasi dari berbagai cadangan makanan seperti protein, karbohidrat, dan lipida (lemak) serta akumulasi fotosintat yang berada dibatang dan daun. Selama pertumbuhan, tanaman mengalami fotosintesis, melakukan fotosintesis tanaman memerlukan unsur hara, semakin banyak unsur hara yang diserap tanaman, hasil akumulasi fotosintat akan semakin besar. Menurut Gardner et al, (1991), berat kering merupakan keseimbangan antara pengambilan karbon dioksia (fotosintesis) dan pengeluaran (respirasi), apabila respirasi lebih besar dari dari fotosintesis, tumbuhan akan berkurang berat keringnya begitu pula sebaliknya. Pemberian pupuk yang mengandung nitrogen tinggi juga mempengaruhi berat kering tanaman. Sarief (1986), menyatakan bahwa ketersediaan unsur hara dalam jumlah yang cukup untuk pertumbuhan tanaman, menyebabkan proses pembelahan, pembesaran dan pemanjangan sel akan berlangsung optimal yang mengakibatkan organ tanaman tumbuh cepat sehingga mempengaruhi nilai berat kering suatu tanaman. Berat kering tanaman berhubungan positif cukup erat dengan kadar nitrogen dalam tanah dan serapan nitrogen oleh tanaman. Semakin tinggi kadar nitrogen dan serapan nitrogen yang meningkat menyebabkan kebutuhan nitrogen pada fase vegetatif tanaman tercukupi, sehingga dapat meningkatkan biomassa tanaman.
Rasio akar-tajuk tertinggi pada perlakuan A1B1 yaitu sebesar 0,40 sedangkan yang terendah pada perlakuan A3B5 yaitu sebesar 0,01 (tabel 2). Nilai rasio akar tajuk menunjukkan dominan ke tajuk atau ke perakaran. Menurut Gardner et al, (1991) peningkatan nitrogen mempengaruhi pertumbuhan pucuk dibandingkan pertumbuhan akar. Perlakuan $100 \%$ KL saat ditambahkan pupuk daun memperlihatkan angka rasio akar tajuk yang kecil (A1B4 dan A1B5) sehingga dapat dikatakan bahwa pertumbuhan dominan ke arah tajuk. Rasio akar tajuk meningkat karena beberapa faktor diantaranya suplai air, rendahanya suplai nitrogen, rendahnya oksigen tanah dan temperature tanah yang rendah (Fitter dan Hay, 1998).

Berdasarkan penelitian yang telah dilakukan pada kondisi cekaman air 75\%, 100\%, dan 125\% KL pemberian pupuk daun yang terbaik untuk pertumbuhan tanaman sawi yang meliputi luas daun, jumlah klorofil, jumlah daun, berat basah, berat kering, dan rasio akar-tajuk adalah konsentrasi $3 \mathrm{~g} / \mathrm{L}$.

\section{DAFTAR PUSTAKA}

Adams, HD, Luce, CH, Breshears, D, Allen, CD, Weiler, Hale, VC, \& Huxman, TE, 2012, Ecohydrological consequences of drought-and infestation-triggered tree die-off: insights and hypotheses, Ecohydrology, vol. 5, no. 2, hal. 145-159.

Aditama, S, 2011, Pengaruh Berbagai Pupuk Daun terhadap Pertumbuhan Kangkung Darat (Ipomea reptans Poir.), Skripsi, Institut Pertanian Bogor, Bogor https://repository.ipb.ac.id/jspui/bitstream/123 456789/52843/1/A11sad1.pdf

Fitter, AH \& Hay, RKM, 1998, Fisiologi Lingkungan Tanaman, Penerjemah Sri Andani dan Purbayanti, ED, UGM Press, Yogyakarta

Gardner, Pearce, RR, \& Mitchell, RI, 1991, Fisiologi tanaman budidaya, UI press, Jakarta

Hardjowigeno, S, 2003, 'Ilmu Tanah', Presindo, Jakarta

Harjadi, SS, 1991, 'Pengantar Agronomi', PT. Gramedia, Jakarta

Lingga, P \& Marsono, 2007, 'Petunjuk Penggunaan Pupuk’, Edisi Revisi, Penebar Swadaya, Jakarta 
Manan, AA, \& Mahfudz, A, 2015, Pengaruh Volume Air dan Pola Vertikultur terhadap Pertumbuhan dan Hasil Sawi Hijau (Brassicajuncea L.), vol. 12, no.1, hal. 33-43

Manuhuttu, APH, Rehatta \& Kailola, JJG, 2014, Pengaruh Konsentrasi Pupuk Hayati Bioboost terhadap Peningkatan Produksi Tanaman Selada (Lactuca sativa L.), Agrologia, vol. 3, no.1, hal. $18-27$

Moctava, MA, Koesriharti \& Dawam, M, 2013, Respon Tiga Varietas Sawi (Brassica rapa L.) terhadap Cekaman Air, Jurnal Produksi Tanaman, vol. 1, no. 2, hal. 90-98, issn 23383976

Prasetyo, AG, 2014, Pengaruh Konsentrasi dan Waktu Pemberian Pupuk Daun Gandasil D Terhadap Pertumbuhan dan Hasil Tanaman Kubis Bunga (Brassica oleracea L.), (Skripsi), Fakultas Pertanian Universitas Muria Kudus, Kudus

http://eprints.umk.ac.id/4280/1/HALAMAN_J UDUL.pdf

Sari, ER, Udayana, C, \& Wardiyati, T, 2011, Pengaruh Volume Pemberian Air dan Konsentrasi Pupuk Daun terhadap Pertumbuhan Vegetatif Tanaman Anggrek (Dendrobium undulatum), Buana Sains, vol. 11, no. 1, hal. 77-82

Sarief, S, 1986, 'Kesuburandan Pemupukan Tanah Pertanian', Pustaka Bejana, Jakarta

Shobirin, I, 2015, Pengaruh Dosis Pupuk Nitrogen dan Pupuk Daun Terhadap Pertumbuhan dan Hasil Tanaman Kangkung (Ipomoea reptans) (Skripsi), Sekolah Tinggi IlmuPertanian Dharmawacana Metro, Lampung

Sitompul, SM, \& B, Guritno, 1995, 'Analisis Pertumbuhan Tanaman', Gadjah Mada University Press, Yogyakarta

Sompotan, S, 2013, Hasil Tanaman Sawi (Brassica juncea L.) terhadap Pemupukan Organik Dan Anorganik, geosains, vol. 2, no. 1, hal. 14-17, ISSN: 2252-8717

Taiz, L \& Zeiger, E, 2002, Plant Physiology, Sinauer Associates, inc, Sunderland

Usman, M, 2010, 'Budidaya Tanaman Sawi', Balai Pengkajian Teknologi Pertanian Riau, Pekanbaru 